\title{
Studies on the Pezizales
}

\author{
HARRI HARMAJA
}

HARMAJA, H. 1986: Studies on the Pezizales. - Karstenia 26: 41-48.

\begin{abstract}
The following new species of the Pezizales (Ascomycetes) are described: Gyromitra accumbens Harmaja (type from Switzerland), Gyromitra columbiana Harmaja (type from British Columbia), Gyromitra mcknightii Harmaja (type from Yugoslavia), Leucoscypha ovilloides Harmaja (type from Finland), Peziza alcidis Harmaja (type from Finland), Peziza kallioi Harmaja (type from Finland), Peziza lohjaënsis Harmaja (type from Finland), Peziza perparva Harmaja (type from Finland), Pseudombrophila maekinenii Harmaja (type from Finland), and Pseudombrophila obliquerimosa Harmaja (type from Finland). The following new combinations are made: Gyromitra fluctuans (Nyl.) Harmaja, Gyromitra geogenius (Donad.) Harmaja, Gyromitra microspora (Donad. \& Boz.) Harmaja, Gyromitra parvispora (Trigaux) Harmaja, Otidea integra (Bres.) Harmaja, and Otidea unicisa (Peck) Harmaja. The nomenclature and typification of some species of Gyromitra Fr. are clarified. Otidea (Pers.) Bon. is amended so as to include rough-spored species. Gyromitra warnei (Peck) Harmaja is reported as new to Finland and Otidea integra as new to Sweden.
\end{abstract}

Harri Harmaja, Botanical Museum, University of Helsinki, Unioninkatu 44, SF-00170 Helsinki, Finland

\section{Gyromitra accumbens Harmaja, n. sp.}

Discina accumbens Rahm, Schweiz. Z. Pilzk. 48: 80. 1970 (not validly published: Latin diagnosis present but designation of type missing). - Gyromitra accumbens (Rahm) Harmaja, Karstenia 15: 30. 1976 (not validly published). - Holotype designated here: Switzerland, Graubünden, Arosa, Prätschwald, alt. ca. 1800 m, 14.V.1966 Ernst Rahm (Herb. E. Rahm).

Gyromitra columbiana Harmaja, n. sp. - Fig. 1

Gyromitrae esculentae satis proxima. Ab ea praecipue differt sporis minoribus $(13-18 \times 7.5-8.5 \mu \mathrm{m})$ cum guttulis oleosis maioribus 4.5-6 $\mathrm{mm}$ in diametro. Typus: Canada, British Columbia, Shuswap Highland, Trophy Mountain, ca. $4 \mathrm{~km} \mathrm{SW}$ of summit, upper oroboreal zone, cut-over area in Abies lasiocarpaPicea engelmannii forest, by temporary logging road, alt. ca. $1500 \mathrm{~m}, 51^{\circ} 47^{\prime} \mathrm{N}, 119^{\circ} 55^{\prime} \mathrm{W}, 30$.VII. 1980 Teuvo Ahti $39236(\mathrm{H})$.

Apothecium differentiated into pileus and stipe; pi- leus indistinctly lobate, fairly densely folded, dark brown; stipe short. Excipulum of thin-walled textura intricata throughout. Paraphyses filiform; apices predominantly clavate, some being subcapitate, 6-11 $\mu \mathrm{m}$ in diam, with brown encrustation. Asci eight-spored, with inamyloid walls. Spores $13-18 \times 7.5-8.5 \mu \mathrm{m}$, predominantly ellipsoid, some being subfusiform, slightly inequilateral; secondary wall persistent, continuous, strongly cyanophilic, practically smooth, slightly inflated toward spore ends (ca. $0.5 \mu \mathrm{m}$ in cotton blue); containing two equally large oil drops $4.5-$ $6 \mu \mathrm{m}$ in diam.

G. columbiana is a member of subg. Gyromitra and is closely related to G. esculenta (Pers.: Fr.) Fr. and especially to G. infula (Schaeff.: Fr.) Quél. From the former it is distinguished mainly by the distinctly smaller spores with larger oil drops (cf. Harmaja 1979a). From $G$. infula it is separated by the folded hymenium, the essentially clavate paraphysis tips, and the shorter spores (cf. Harmaja 1969). It is not yet possible to judge whether $G$. columbiana has a vernal or an autumnal fruiting pattern. 

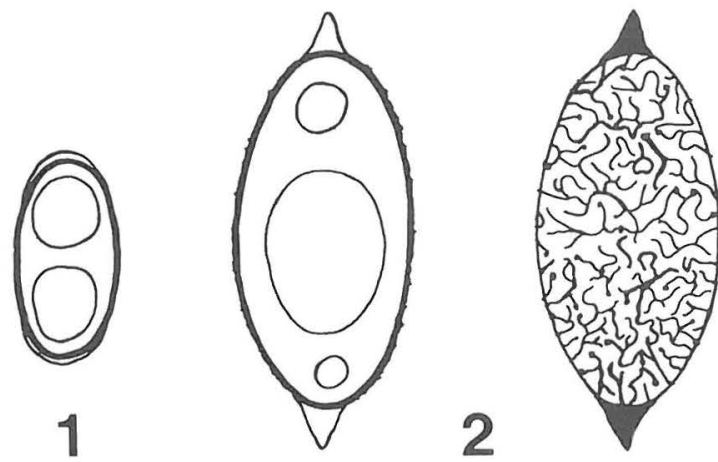

Figs. 1-2. Mature spores drawn in heated cotton blue, $X$ 1400. - 1: Gyromitra columbiana (type). - 2: G. mcknightii (type).

\section{Gyromitra fluctuans (Nyl.) Harmaja, n. comb.}

Peziza fluctuans Nyl., Notis. Sällsk. F. Fl. Fennica Förh. 10: 9. 1868 (preprint: Obs. Pezizas Fenniae). - Type: Finland, Uusimaa, Helsinki, Laajasalo, Tahvonlahti ('Helsinge, Degerö, Stansvik'), on sandy ground, beginning of May, 1860 P.A. Karsten (holotype, H; 2 isotypes: Herb. W. Nylander and Herb. P.A. Karsten no. 2960, both H; all examined).

Discina macrospora Bubák, Ann. Mycol. 2: 395. 1904. Gyromitra macrospora (Bubák) Harmaja, Karstenia 13: 56. 1973. - Type: From Czechoslovakia (lectotype, BPI, apparently selected by McKnight 1969; examined).

The forgotten Peziza fluctuans Nyl. was found to provide an older name for Gyromitra macrospora (Bubák) Harmaja (see Harmaja 1973 and McKnight 1969). G. macrospora was never reported from Finland. Nylander's species, when noticed at all, has apparently always been considered a synonym of $G$. perlata (Fr.) Harmaja (Discina perlata (Fr.) Fr.). The isotype specimen from Karsten's herbarium is large and contains abundant mature spores.

When revising the genus Gyromitra in Finland, I found that the current concept of G. perlata is collective, four species being involved: G. perlata s.str., G. fluctuans (syn. G. macrospora), G. warnei (Peck) Harmaja, and G. mcknightii Harmaja n.sp. (see below). G. perlata is frequent in Finland, G. fluctuans rather infrequent, and the remaining two rare. $G$. warnei (see Harmaja 1973 and McKnight 1969) is new to Finland, being represented by the following specimens, collected from fertile sites (all in $\mathrm{H}$ ): VarsinaisSuomi: Lohja rural commune, 1968, 1970, 1972 Harmaja; 1972 A. Mäkinen. Uusimaa: Espoo, 1975 Korhonen 1326.

Gyromitra geogenius (Donad.) Harmaja, n. comb.

Discina geogenius Donad. ('geogenia (Rahm) Donad.'),
Mycol. Helvetica 1: 254. 1984. - Discina perlata (Fr.) Fr. var. geogenius Rahm, Schweiz. Z. Pilzk. 48: 79.1970 (not validly published: designation of type missing). - Gyromitra geogenius (Rahm) Harmaja ('geogenia'), Karstenia 15: 30. 1976 (not validly published). - Holotype ('lectotype'): Switzerland, Graubünden, Arosa, Prätschwaldweg, alt. 1770 m, 10.VI.1964 Ernst Rahm (Herb. E. Rahm).

Gyromitra mcknightii Harmaja, n. sp. - Fig. 2

A Gyromitra perlata, quae valde affinis est, differt forma sporarum plerumque \pm ellipsoideo, guttulis oleosis lateralibus sporarum minoribus (diametro 2-6 $\mu \mathrm{m}$ ), ornamentatione sporarum delicatulo et apiculo sporarum minore $(2.2-4 \times 2.2-3.6 \mu \mathrm{m})$. - Typus: Yugoslavia, Crna Gora (Montenegro), $40 \mathrm{~km}$ NNE of Nikšić, Žabljak, Mt. Durmitor near Crno Jezero, Picea-Abies forest, on soil on trailside, alt. ca. $1500 \mathrm{~m}$, 17.VI.1971 Orvo Vitikainen 7140 (H). Another specimen examined: Finland, Uusimaa, Sipoo, on soil, 16.V.1943 Sandström (H).

Apothecia and excipulum much like those of G.perlata. Paraphyses filiform; apices clavate to subcapitate, $6-10(-15) \mu \mathrm{m}$ in diam; contents with brown granules; end cells ca. 50-80 $\mu \mathrm{m}$ long. Asci eight-spored, with inamyloid walls. Spores (measurements in Melzer's reagent) $23-30 \times 12-14 \mu \mathrm{m}$ (without apiculi), predominantly ellipsoid (the remainder subfusiform), weakly inequilateral, both sides distinctly convex also in side view; secondary wall persistent, continuous, cyanophilic, with very low verruculose and labyrinthine ornamentation, forming a subacute apiculus, 2.2-4 $\mu \mathrm{m}$ long and 2.2-3.6 $\mu \mathrm{m}$ wide basally, at each spore end; containing one large central oil drop and two small ( $2-6 \mu \mathrm{m}$ in diam) often indistinct lateral drops (the lateral drops may be absent).

This new species is named in honour of Dr. K.H. McKnight (Beltsville, Virginia, U.S.A.), who has contributed so much to the study of the North American species of Gyromitra s.lat.

G. mcknightii is very closely related to $G$. perlata (Fr.) Harmaja, differing from it in the following spore characters: the spore shape is predominantly ellipsoid and only weakly inequilateral, the ornamentation is more delicate, tending to be labyrinthine, the apiculi are smaller, especially narrower, the oil drops are often indistinct, and the lateral oil drops are smaller. The hymenium may be somewhat darker brown. In G. perlata, the spores are predominantly subfusiform and fairly distinctly inequilateral (one side is almost straight in side view), the ornamentation is fairly coarse, tending to form a reticulum, the apiculi measure $3.2-4.5 \times 3.5-4.5 \mu \mathrm{m}$, the oil drops are \pm distinct, and the lateral oil drops measure $4-7 \mu \mathrm{m}$ in diam.

G. mcknightii is apparently a widespread species, 
but has not been distinguished from G. perlata. 'Discina perlata' in McKnight (1969) includes material of the present species: Fig. $4 \mathrm{c}$ in that paper shows its typical spores.

Gyromitra microspora (Donad. \& Boz.) Harmaja, n. comb.

Discina microspora Donad. \& Boz. in Donad., Mycol. Helvetica 1: 260. 1984.

Gyromitra parvispora (Trigaux) Harmaja, n. comb.

Discina parvispora Trigaux, Doc. mycol. 16(61): 13. 1985.

\section{Leucoscypha ovilloides Harmaja, n. sp.}

$A$ Leucoscypha ovilla differt praesertim sporis brevioribus $(28-44 \times 10-15 \mu \mathrm{m})$ tunica contentiaque earum dissimilibus. - Typus: Finland, Koillismaa, Kuusamo, Oulanka National Park, ravine of the brook Tulilammenpuro, moist grass-herb forest on calcareous soil, in decaying twig of Picea abies, alt. $225 \mathrm{~m}$, Grid $27^{\circ} \mathrm{E}$ 7365:609, 26.VIII.1970 Harri Harmaja (H).

This new species is very like Leucoscypha ovilla (Peck) Harmaja (holotype in NYS compared) (syn. $L$. rhodoleuca (Bres.) Svrček: type material in S examined), differing from it in four features: the spores of L. ovilloides are shorter, measuring 28-44 $\times 10-$ $15 \mu \mathrm{m}$ when mature, the spores are generally broader in proportion to their length, the cyanophilic secondary spore wall becomes very thin towards spore maturity and, as the contents are cyanophobic, the mature spores appear practically hyaline in heated cotton blue, and fourthly the spores (except in $\mathrm{KOH}$ ) are filled with small oil drops in addition to the two large ones. The mature spores of $L$. ovilla s.str. measure about $40-55 \times 10-14 \mu \mathrm{m}$, their cyanophilic secondary wall remains thicker, so that the mature spores are distinctly blue in heated cotton blue mounts, especially since their contents, too, seem to be cyanophilic, and they do not contain so many small oil drops besides the two large ones. L. ovilloides has earlier been described by Harmaja (1977, erroneously as L. ovilla because the type of Peziza ovilla Peck was not available at that time) and by Dissing \& Sivertsen (1983, as Rhodoscypha ovilla (Peck) Diss. \& Siv., the characters are mostly those of $L$. ovilloides). The differences between the spores of the species are excellently illustrated in Fig. 4 of the latter paper: ' $a$ ' shows the spores of $L$. ovilloides and ' $d$ ' and ' $e$ ' those of $L$. ovilla (the fact that the spores are in different mountants does not affect the comparison in this case; it appears that, contrary to what is written in the legend, the magnification in ' $a$ ' is the same as in ' $d$ ' and 'e').

L. ovilloides grows on bare soil, among mosses (apparently not bryophilous), and in decaying wood of angiosperms and gymnosperms, on fertile, preferably calcareous, ground. It possesses a wide northern distribution. L. ovilla s.str. is probably very rare and possibly more southern.

Dissing and Sivertsen (1983) considered that it is not possible to distinguish two taxa on the basis of the spore characters of $L$. ovilla s.lato and their treatment covers both species. Moreover, they established a new monotypic genus, Rhodoscypha Diss. \& Siv., for this single species. I do not accept the genus Rhodoscypha, but include both species in Leucoscypha Boud. for the reasons presented by me previously (Harmaja 1977): there are only quantitative differences between $L$. ovilla coll. and L. leucotricha (Alb. \& Schw.: Fr.) Boud., the type species of Leucoscypha. However, the arguments given by Dissing and Sivertsen (1983) for maintaining the genus Neottiella (Cooke) Sacc. for Peziza rutilans Fr. and allied species appear valid.

\section{Specimens examined}

Finland. Perä-Pohjanmaa: Rovaniemi rural commune, 1975 Ulvinen (OULU). Koillismaa: Kuusamo, 1970, 1978 Harmaja (H), 1978 Sivertsen (OULU), 1978 Ulvinen (OULU). Sweden. Värmland: Gräsmark, 1981 P. \& I. Kytövuori 81352 (H). Medelpad: Borgsjö, 1983 Vauras 1514 (TUR). Norway. Nordland: Rana, 1975 Dissing \& Sivertsen MO $75.61(\mathrm{H})$, 1976 Ohenoja (OULU). U.S.A. New York: Slaterville, 1947 Rogerson \& Korf (CUP). Canada. Québec: New Québec Terr., Schefferville, 1967 Mäkinen 67-1375 and 67-1375a (TUR).

Otidea integra (Bres.) Harmaja, n. comb.

Otidea concinna (Pers.: Fr.) Sacc. f. integra Bres., Fungi Tridentini 2: 70. 1898. - Original material examined: Italy, Trento, leg. G. Bresadola (PC, Herb. E. Boudier).

Coloured illustration: Bresadola: Iconogr. mycol. 25: pl. 1226. 1933.

This taxon, undoubtedly worthy of specific rank, differs from $O$. concinna (O. cantharella (Fr.) Sacc. sensu Harmaja 1974a) as given by its author: the apothecia are smaller, \pm entire, and have externally branched ribs and pits near the base, and the paraphysis tips are wider, reaching a diameter of $7.5 \mu \mathrm{m}$ (up to $5 \mu \mathrm{m}$ thick in $O$. concinna). Moreover, I found a difference in the length of the terminal cells of the paraphyses: predominantly $25-45 \mu \mathrm{m}$ in $O$. integra $v s$. $15-35 \mu \mathrm{m}$ in $O$. concinna. O. integra is also closely related to $O$. phlebophora (Berk. \& Br.) Sacc. (see Harmaja 1974a, as Flavoscypha phlebophora (Berk. \& Br.) Harmaja), which likewise has unsplit apothecia, differing from it in the slightly larger and fleshier apothecia, the pinkish fresh hymenium, the predomi- 


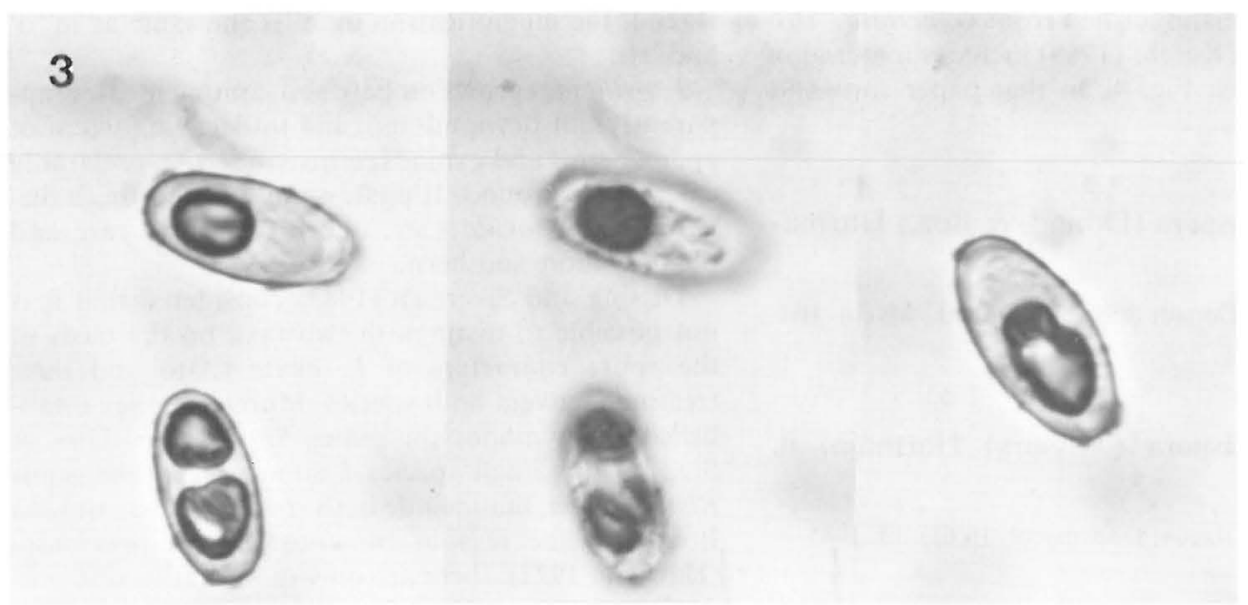

Fig. 3. Otidea unicisa, mature spores in heated cotton blue, $\times 1500$ (type). Photo: Mauri Korhonen.

nantly curved paraphyses, and the thicker apices of the paraphyses (in $O$. phlebophora the fresh hymenium is yellow, the great majority of the paraphyses are straight, and the width of the paraphysis tips does not exceed $5 \mu \mathrm{m}$ ). The anatomy of the excipulum displays slight differences in these three closely related species, while their spores are very similar, measuring about 10-12 × 5-6 $\mu \mathrm{m}$ (cf. Harmaja 1974a). All three species prefer \pm bare more or less calcareous soil in predominantly deciduous woods, and are unlikely to occur north of the northern limit of Quercus robur.

$O$. integra is apparently very infrequent, and it is seldom mentioned in the literature; it may have been considered a mere modification of $O$. concinna (which at times produces one or two entire but irregular apothecia, these being true modifications and not deserving taxonomic recognition). Unlike the two other species (Harmaja 1974a), O. integra is not known from Finland. The following specimen appears to be the first record of $O$. integra from Sweden: Uppland: Älvkarleby, Sågarbo, 24.VIII.1974 Kytövuori 5134a (H).

Otidea unicisa (Peck) Harmaja, n. comb.

Peziza unicisa Peck, New York St. Mus. Rep. 26: 81. 1874. Type examined: U.S.A., New York, Lewis Co., Croghan, Jelt House, September, C.H. Peck (holotype, NYS).

O. unicisa is easily distinguished from all the other species of Otidea (Pers.) Bon. by its delicately ornamented spore wall, reported here for the first time. The ornamentation is formed in the persistent cyanophilic probably continuous secondary wall and consists of irregular thin winding ridges and warts, which form patches of reticulum in places and are coarsest at the spore ends, where they reach a height of ca. $1 \mu \mathrm{m}$. The spores measure $12.5-16 \times 6.2-7.5 \mu \mathrm{m}$ and are essentially ellipsoid. Macroscopically 0 . unicisa is fairly similar to $O$. onotica (Pers.: Fr.) Fuckel, both when fresh and when dry; however, the apothecia of O. unicisa are probably invariably truncate (not elongated) and their outside is generally slightly darker and more reddish brown when dry.

$O$. unicisa has been badly neglected: the name has been considered a synonym of either $O$. onotica or $O$. leporina (Batsch: Fr.) Fuckel, and specimens of the species have likewise apparently usually been identified as $O$. onotica or $O$. leporina, the roughness of the spores having been missed. $O$. unicisa appears to be frequent in the temperate broad-leaved woods of eastern North America. I have seen specimens from Massachusetts (FH), New Hampshire (FH), New York (NYS), Pennsylvania (Ellis \& Everhart: N.A. Fungi, 2nd ser., 1778; FH, H), and Vermont (FH).

By including a rough-spored species in Otidea, I amend its concept to embrace species whose spores have persistent cyanophilic secondary walls, which can also be rough. As the species otherwise fits perfectly with the current concept of Otidea, I have no reason to exclude it. The spores of Otidea are generally thought to be perfectly smooth, and I earlier observed only a temporary secondary wall, or perispore, in the genus (Harmaja 1974b). Due to this amendment, the delimitation of Otidea from Tarzetta (Cooke) Lamb. and Sowerbyella Nannf. has to be redefined, though the latter are definitely independent genera.

Peziza alcidis Harmaja, n. sp.

Pezizae fimeti peraffinis sed $a b$ ea differt sporis minoribus (14-16 $\times 7-8 \mu \mathrm{m})$ et substrato fimo alcidis. 

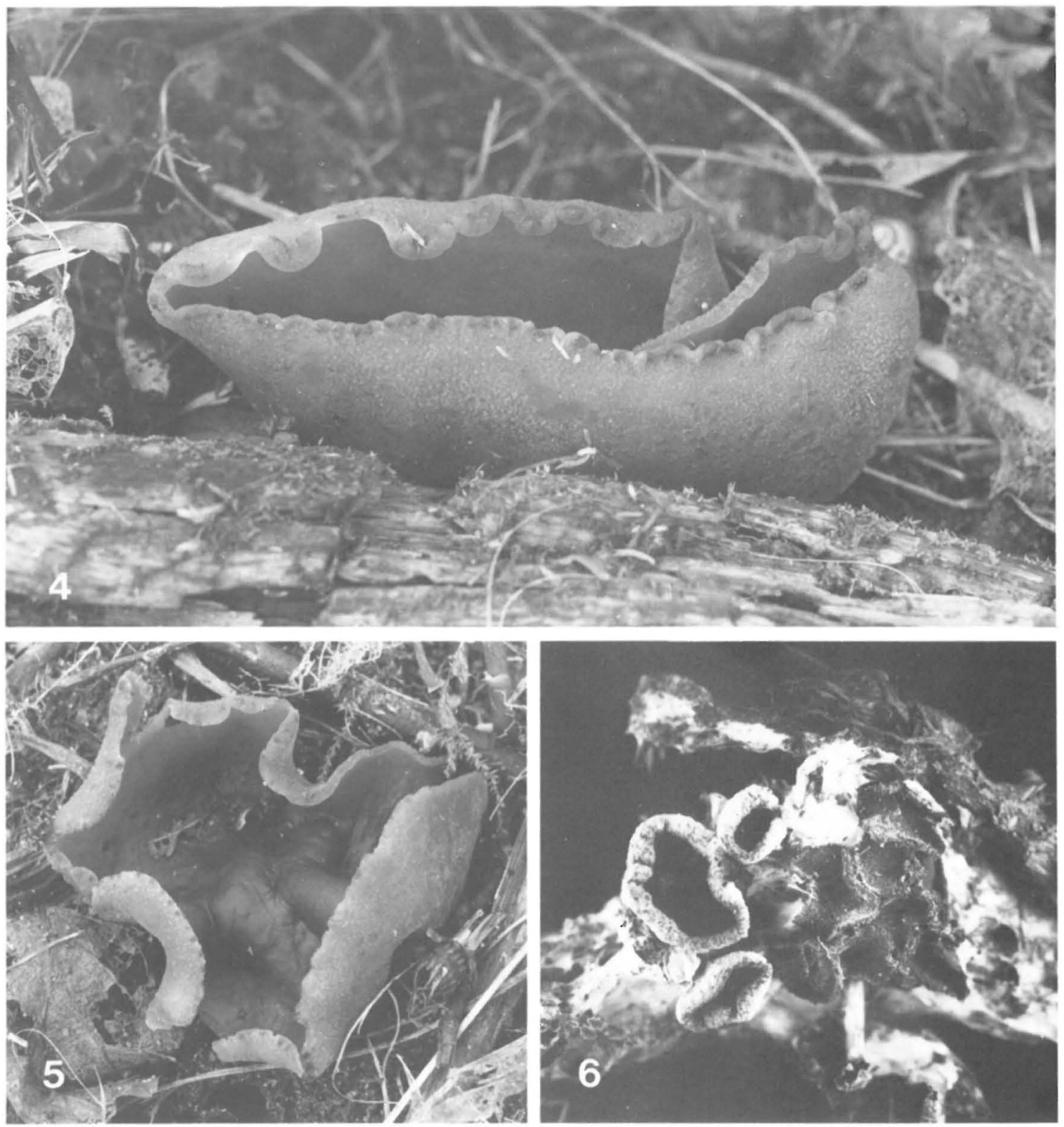

Figs. 4-6. Ascomycete apothecia. - 4-5: Peziza lohjä̈nsis fresh in situ, $\times 2.8$ (Finland, Uusimaa, Helsinki, Kumpula, Grid $27^{\circ} \mathrm{E}$ 6678:386, 15.V.1982 Saarenoksa 482; H). - 6: Pseudombrophila tetraspora (3 apothecia to the left) and $P$. aggregata (several tightly apressed apothecia to the right); apothecia of $P$. tetraspora are larger, thicker, and externally densely white-pubescent, and mature more slowly. Dried mixed stand, $X 4.7$ (Finland, Uusimaa, Nurmijärvi, 2.V.1978 Askola 580; H). Photo: Mauri Korhonen. 
- Typus: Finland, Uusimaa, Inkoo, Rådkila, \pm mesic acid coniferous heath forest (OMT site type), in dung of Alces alces, alt. ca. $15 \mathrm{~m}$, Grid $27^{\circ} \mathrm{E} 6665: 339$, 9.XI.1977 Harri Harmaja (H).

$P$. alcidis is closely related to $P$. fimeti (Fuckel) Seaver, differing mainly in the smaller spores (14-16 $\times 7-8 \mu \mathrm{m})$ and the occurrence on elk dung. There may also be differences in the tips of the paraphyses. $P$. alcidis has been found in many places in Finland. The spores of $P$. fimeti exceed $16 \mu \mathrm{m}$ in length and $8 \mu \mathrm{m}$ in width and it occurs on the dung of domestic animals, viz. the cow and horse. Variable dimensions are given in the literature, however, for spores exceeding these limits in specimens from the dung of cows and horses, and the exact meanings of the old names $P$. fimetosa $\mathrm{Fr}$. ( $P$. fimetaria Schum. non $P$. fimetaria (Pers.: Fr.) Fr.), $P$. fimeti, and $P$. bovina Phill, should be clarified.

The Finnish species of the genus Peziza L.: Fr. will be treated comprehensively in a forthcoming paper.

\section{Peziza kallioi Harmaja, n. sp.}

A Peziza badioconfusa praecipue differt mycelio basali apothecii violaceo, sporis brevioribus $(15-19 \times 7.5-$ $10 \mu \mathrm{m})$, forma sporarum ellipsoideo, ornamentatio sporarum dissimili, habitatione dissimili, fructificatione seriore et distributione hyperborea. - Typus: Finland, Inarin Lappi, Inari, Muddusjärvi, Syrminiemi, $\mathrm{N}$ of Syväranta, brookside rich forest, Grid $27^{\circ} \mathrm{E} 7653: 493$, 9.VIII.1965 Kaarina Mäkinen (TUR).

Prof. Paavo Kallio (Turku) is well known for his achievements in Finnish mycology and is especially interested in the problems of subarctic mycology. I have pleasure in naming the new species in his honour.

This very characteristic species is currently known in Fennoscandia under the name Peziza badioconfusa Korf (Aleuria olivacea Boud., non Peziza olivacea Batsch: Fr. nec P. olivacea Quél.; Korf 1955). However, this is a misinterpretation of $P$. badioconfusa. I had long doubted the correctness of the prevailing interpretation, and my recent study of the holotype of $P$. badioconfusa (in PC, Herb. E. Boudier) proved that it is indeed a different species; it has a more southern distribution and probably does not occur in Fennoscandia. Other species of Peziza besides $P$. kallioi have no doubt been confused with $P$. badioconfusa; there are several dark brown species which have warted spores.

$P$. kallioi differs from $P$. badioconfusa chiefly in the conspicuous bright violet basal mycelium of the apothecia, the shorter $(15-19 \times 7.5-10 \mu \mathrm{m})$ and ellipsoid spores, the spore ornamentation, which consists of warts that vary somewhat in size throughout the spore, being \pm distinctly larger at the spore ends, the habitat (usually) in moist or wet rich woods and bushes, especially by brooks, mostly in decaying angiosperm wood, the fruiting in summer and autumn, and the pronouncedly boreal distribution. P. badioconfusa has spores which measure (occasional macrospores excluded) $17.5-22.5 \times 7.5-10 \mu \mathrm{m}$, are predominantly subfusiform, and whose ornamentation besides warts includes elongated and curved elements, all of which are fairly uniform in size throughout the spore; the species is not known to prefer moist or wet habitats or wooden substrates, it fruits in spring and early summer, and has a more southern distribution (type collected in Nice by the Mediterranean). The figures of the spores of $P$. badioconfusa in Le Gal (1937, as Galactinia olivacea) are excellent.

Judging from certain reports of $P$. 'badioconfusa', P. kallioi is sometimes fairly abundant locally in northern Finland (e.g. Ulvinen et al. 1981), northern Sweden (e.g. Ryman \& Holmåsen 1984), northern or elevated areas of Norway (e.g. Schumacher 1979), and northernmost North America (e.g. Wells \& Kempton 1967).

Peziza lohjaënsis Harmaja, n. sp. - Figs. 4-5

Apothecia $1-7 \mathrm{~cm}$ in diametro, mediocriter brunnea, extus albofurfuracea et cum nonnullis granulis brunneis, margine parce lacerato, e mycelio basali albo pseudostipitata. Paraphyses filiformes, apicibus 6-10 $\mu \mathrm{m}$ in diametro. Asci octospori, tunica brunneola superne

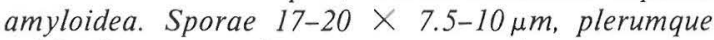
subfusiformes, tarde maturescentes, demum eguttulatae et verruculosae cum verrucis maioribus ad apicibus sporarum. Vere in nemoribus frondosis. -Typus: Finland, Varsinais-Suomi, Lohja rural commune, Jalassaari, Heimo, slightly moist, predominantly deciduous (e.g. Populus tremula), rich woods on somewhat calcareous ground, on bare mull, alt. $45 \mathrm{~m}$, Grid $27^{\circ} \mathrm{E} 6682: 329,30 . V .1982$ Harri Harmaja (H).

Apothecia $1-7 \mathrm{~cm}$ broad, when fresh medium brown on both sides or with olive tint on hymenium, when dry with a dark brown (at times olive-tinged) hymenium and whitish or pale brown outside, often laterally compressed; margin usually slightly lacerate; outer surface very faintly white-furfuraceous with brown granules present near margin; a pseudostipe is formed by the white basal mycelium. Excipulum composed of layers of filamentose hyphae and inflated cells, with short projecting hyphae outermost; conspicuous fairly broad brown septal collars present; globose intercalary chlamydospores, $6-8 \mu \mathrm{m}$ in diam and with hyaline to brown verruculose walls, present in outer part. Paraphyses filiform; apices clavate, 6$10 \mu \mathrm{m}$ thick; contents with small pale or medium brown particles. Asci eight-spored; walls brownish, 
amyloid at apex. Spores 17-20 × 7.5-10 $\mu \mathrm{m}$, subfusiform and narrowly ellipsoid, a few being oblong; remaining smooth for a long time even in large apothecia, but persistent cyanophilic secondary wall finally developing an ornamentation consisting of warts, which become larger towards spore ends; contents eguttulate at maturity. Ecology. Occurs in fertile predominantly deciduous, often slightly moist, rich woods, almost always associated with Populus tremula, on bare mull and in scanty plant litter, occasionally in decaying deciduous wood, often hidden under leaves; only in spring.

P. lohjaënsis is known from several places in South Finland. I have not found reports of it in the literature under any name, though it is most characteristic. The only species which shows fairly distinct affinity to it is $P$. phaeotheca McKnight \& Dublin (McKnight \& Dublin 1979), a snowbank species from western North America, which likewise possesses brownish ascus walls. $P$. phaeotheca has broader spores with different ornamentation and dissimilar paraphyses. $P$. nivalis (Heim \& Remy) Moser and $P$. ninguis Donad. \& Trimbach, too, resemble somewhat $P$. lohjaënsis (cf. Donadini 1980).

\section{Peziza perparva Harmaja, n. sp.}

Pezizae fimeti probabiliter affinis; ab ea praecipue differt apotheciis perexiguis (diametro ca. $1-1.5 \mathrm{~mm}$ ), sporis distincte minoribus (11-13.5 × 6-7 $\mathrm{m}$ ) tunica subtiliter ornamentato, et habitatione ad quisquilias plantarum in loco ammonioso. - Typus: Finland, Varsinais-Suomi, Rymättylä, Raulahti, Raula, in dead plant litter on a moist path in woods used by elk, with Byssonectria spp. and Pseudombrophila obliquerimosa, Grid $27^{\circ} \mathrm{E} 6708: 221,18$.VII.1978 Risto Tuomikoski (H).

Apothecia (dry) ca. $1-1.5 \mathrm{~mm}$ in diam, cupulate, sessile, thin, fairly pale brown on both sides; outer surface very finely white-pubescent under lens. Excipulum composed of textura globulosa, with short projecting hyphae outermost. Paraphyses scanty; apices clavate, straight or somewhat curved, 4-6 $\mu \mathrm{m}$ wide; contents \pm homogeneous, \pm colourless. Asci 7-10 $\mu \mathrm{m}$ broad, eight-spored, pleurorhynchous; walls strongly amyloid at very apex where the amyloid layer is ca. $0.8 \mu \mathrm{m}$ thick. Spores $11-13.5 \times 6-7 \mu \mathrm{m}$, narrowly ellipsoid, tending to be subfusiform, somewhat brownish in Melzer's reagent; secondary wall cyanophilic, persistent but getting thinner towards maturity, very delicately ornamented with incompletely labyrinthine pattern (separate warts and reticulum in places), the markings being ca. $0.2 \mu \mathrm{m}$ high at the spore ends and slightly lower elsewhere; contents irregularly granular or with some small oil drops which tend to be situated near spore ends; de Bary bubbles common. Ecology. Found in moist place on a forest path used by elks, growing in dead plant litter apparently earlier impregnated by elk urine, intimately associated with Byssonectria spp. and Pseudombrophila obliquerimosa; in the height of summer.

$P$. perparva is a characteristic species, and its apothecia may be the smallest in the genus. It is difficult to tell which species would be its closest congeneric relatives, but probably it belongs to the neighbourhood of $P$. fimeti (Fuckel) Seaver (cf. above under $P$. alcidis Harmaja).

$P$. perparva apparently belongs to that curious group of ammonophilous species which seem to use the urine of the elk (Alces alces) and related species as the source of nutrition. Among the Pezizales, only representatives from the genera Byssonectria Karst. and Pseudombrophila Boud. (syn. Nannfeldtiella Eckbl.) have hitherto been assigned to that group.

\section{Pseudombrophila maekinenii Harmaja, n. sp.}

Pseudombrophilae minoris valde affinis, ab ea plerumque sporis minoribus (9-12 $\times 5.5-7 \mu \mathrm{m})$ differt. Typus: Finland, Koillismaa, Kuusamo, Oulanka National Park, Merioja, dry heath forest, on a reindeer path rather near elk dung, associated with Byssonectria aggregata and Pseudombrophila aggregata, alt. ca. 220 m, Grid $27^{\circ}$ E 7363:604, 21.VI.1968 Harri Harmaja (H). Another specimen examined: Finland, Uusimaa, Hyvinkää, Kytäjä, Grid $27^{\circ} \mathrm{E}$ 6717:371, 19.V.1970 Harmaja (H).

The species is named in honour of Dr. Yrjö Mäkinen, the Curator of the Botanical Museum of the University of Turku. This eminent mycologist was one of the two authors who reported the genus Nannfeldtiella Eckbl. (i.e. the 'Nannfeldtiella group' of the genus Pseudombrophila Boud., Pyronemataceae) as new to Finland. A determination label for the type specimen of the present species written jointly by Dr. Mäkinen and Mrs Aira Pohjola in 1968 carries the observation: "all the spores abortive', so they were the first to observe the very small spores characteristic of this species (though they included the specimen in $N$. aggregata Eckbl. = P. aggregata (Eckbl.) Harmaja).

$P$. maekinenii is very closely related to $P$. minor Harmaja (one of the segregates of 'Nannfeldtiella' aggregata; see Harmaja 1979b), but its spores measure only 9-12 $\times 5.5-7 \mu \mathrm{m}$ with the apiculi included. The spore apiculi are also smaller and at times concave (they may even be absent). $P$. maekinenii may have a more northern distribution than the related species.

$P$. maekinenii, together with $P$. minor and $P$. aggregata, belongs to the eight-spored species of the 'Nannfeldtiella group'. Their apothecia are very similar 
macroscopically (Fig. 6, to the right). The four-spored species $P$. tetraspora Harmaja and $P$. microtetraspora Harmaja (see Harmaja 1979b) have apothecia dissimilar to those of these three species but mutually very alike (Fig. 6, to the left). The very rare eight-spored $P$. obliquerimosa Harmaja (see below) and four-spored P. guldeniae Svrčk possess apothecia somewhat differing from the above patterns.

A study dealing with the 'Nannfeldtiella group' in Finland is under preparation.

\section{Pseudombrophila obliquerimosa Harmaja, n. sp.}

Pseudombrophilae minoris sat similis sed ab ea differt apotheciis minoribus pallidioribusque et sporis parce minoribus $(11-12.5 \times 5.5-7 \mu \mathrm{m})$ ornamentatione dissimile. - Typus: Finland, Varsinais-Suomi, Rymättylä, Raulahti, Raula, in dead plant litter on a moist path in woods used by elk, with Byssonectria spp. and Peziza perparva, Grid $27^{\circ} \mathrm{E}$ 6708:221, 18.VII.1978 Risto Tuomikoski (H).

$P$. obliquerimosa somewhat resembles $P$. minor Harmaja (Harmaja 1979b), but has smaller apothecia, which are only ca. $1.5 \mathrm{~mm}$ in diam and fairly pale brown when dry; its spores are slightly smaller (11$12.5 \times 5.5-7 \mu \mathrm{m}$, ornamentation included) and more narrowly ellipsoid some being subfusiform, and have different ornamentation. The spore sculpture of $P$. obliquerimosa becomes coarser towards the spore apices where it reaches a height of ca. $0.8 \mu \mathrm{m}$; it consists essentially of low oblique ridges which tend to be anastomosed towards the spore apices.

The tiny apothecia, different spore ornamentation, and possibly different phenology of $P$. obliquerimosa sets it somewhat apart from the strictly vernal ' Nannfeldtiella group' of the genus Pseudombrophila Boud. (cf. Harmaja 1979b and above).

Acknowledgements. Loans of important material were received from the following herbaria: BPI, CUP, FH, NYS, OULU, PC, S, and TUR. I am most grateful to their curators. Mr Mauri Korhonen (Botanical Museum, University of Helsinki) took the photographs and Dr. Juha Viramo provided good working conditions during my stays in Kuusamo at the Biological Station of the University of Oulu.

\section{References}

Dissing, H. \& Sivertsen, S. 1983: Operculate Discomycetes from Rana (Norway) 5. Rhodoscypha gen.nov. and Rhodotarzetta gen.nov. - Mycotaxon 16: 441-460.

Donadini, J.C. 1980: Le genre Peziza 4. Les Pezizes nivales. - Bull. Soc. Mycol. France 96: 247-248.

Harmaja, H. 1969: A neglected species, Gyromitra ambigua (Karst.) Harmaja, n.comb., and G. infula s.str. in Fennoscandia. - Karstenia 9: 13-19.
- 1973: Amendments of the limits of the genera Gyromitra and Pseudorhizina, with the description of a new species, Gyromitra montana. - Karstenia 13: 48-58.

- 1974a: Flavoscypha, a new genus of the Pezizales for Otidea cantharella and $O$. phlebophora. - Karstenia 14: $105-108$.

- 1974b: Observations on the presence of a cyanophilic perispore in the spores of the Pezizales. - Karstenia 14: 123-125.

- 1977: Leucoscypha ovilla n.comb., a species new to Europe, found in northern Finland. - Karstenia 17: 73-76.

- 1979a: Notes on Gyromitra esculenta coll. and G. recurva, a noteworthy species of western North America. Karstenia 19: 46-49.

- 1979b: Studies on vernal species of Gyromitra and Pseudombrophila (syn. Nannfeldtiella). - Ann. Bot. Fennici 16: 159-162.

Korf, R.P. 1955: Discomyceteae exsiccatae, Fasc. 1. - Mycologia 46: 837-841.

Le Gal, M. 1937: Florule mycologique des Bois de la Grange et de l'Etoile (Seine-et-Oise). Discomycètes (suite). Rev. Mycol. (N.S.) 2: 197-222.

McKnight, K.H. 1969: A note on Discina. - Mycologia 61: 614-630.

McKnight, K.H. \& Dublin, M.V. 1979: A new Peziza from the snowbank flora of western America. - Beih. Sydowia 8: $224-227+1 \mathrm{pl}$.

Ryman, S. \& Holmåsen, I. 1984: Svampar. En fälthandbok. $-718 \mathrm{pp}$. Stockholm.

Schumacher, T. 1979: Notes on taxonomy, ecology, and distribution of operculate discomycetes (Pezizales) from river banks in Norway. - Norwegian J. Bot. 26: 53-83.

Ulvinen, T., Ohenoja, E., Ahti, T. \& Alanko, P. 1981: A check-list of the fungi (incl. lichens) of the Koillismaa (Kuusamo) biological province, N.E. Finland. - Oulanka Reports 2: 1-64.

Wells, V. \& Kempton, P.E. 1967: Studies on the fleshy fungi of Alaska 1. - Lloydia 30: 258-268.

Accepted for publication

on 25 March 1986 